\title{
Survey on the flood-prevention of municipal governments during the Danubian flood of the century
}

\author{
BÁRDOS Zoltán ${ }^{1}$
}

\begin{abstract}
Given the risk of flood, inland water and local damage caused by water in Hun- gary, it is essential in most of the settlements to prepare for the protection of the inhabitants, the prevention and reduction of the damages. The protection against the damage caused by water - according to Law LVII of 1995 on water manage-ment - is the duty of the state organs and the local municipal governments. In this article I study the duties of the settlements on water damage defence according to the laws of local governments and water management. I analyse the application of the amended laws during the protective activity of settlements in Fejér County hit by the Danubian flood in 2013.
\end{abstract}

Keywords: risk of damage caused by flood and inland water, local governmental protection, water damage defence.

\section{Introduction}

Serious floods, inland water and local water damage has emerged in the country due to its geographical position and the remarkably extreme hydrological events of the past decade. The floods of the Danube, Tisza and in Borsod county, and the state-wide inland water and local water damage confirm that the settlements, in addition to the central state organs, have essential duties in water damage defence on behalf of the protection of human life and ma-terial goods.

Based on statistical averages in Hungary we can expect small or medium floods every two or three years, significant ones every five or six years and extraordinary floods every ten or twelve years.

While $25 \%$ of the country's territory is directly at risk to floods, overflows can emerge in any settlement of the country at any time of the year due to extreme weather conditions risking the inhabitants' life and their property's safety. [1]

Protection against water damage includes rampart construction, maintenance, operation and prevention which according to the law on water management — are the duties of the state [3: para. 16 (1)] [3: para. 35 (1) b)], the local governments and the parties concerned with damage protection or removal.

Consequently, the accomplishment of the defence work is highly complex and it has tech- nical and administrative duties. The foundation of task execution in a unified system is the precise legal regulation which is indispensable for effective defence.

In the article I examine the alteration of municipal governments' defence activity during water damage defence based on the regulatory amendments.

1 Doctoral Student, Military Technical Ph.D. School, email: bardos.zoltan@katved.gov.hu 


\section{The regulatory provision of local governments' duties of water damage defence}

The most essential rule regulating the operation of the municipal governments of the settle- ments was adopted after the declaration of the Supreme Law. This rule alters the relationship between the local governments and the state management. The law regarding the local gov- ernments of Hungary, 2011. CLXXXIX (Act CLXXXIX of 2011 on the local governments of Hungary - Magyarország helyi önkormányzatairól szóló 2011. évi CLXXXIX. törvény [hereinafter:] Mötv.), relies on the previous municicapl governing regulations, but the role of the government was strengthened, the former legal control was replaced by a legal supervi- sion assuring strong intervention possibilities. Concurrently the economic autonomy of the local governments was given administrative limits. Mötv has transformed the system of local governance duties, and the provision of the compulsory duties has been emphasized in the new law. The assurance of voluntary and assumed tasks has been subjected to conditions by the new rule. [2]

As opposed to the rules of the previous Constitution, the new regulation puts an em- phasis on the character of the local governments within the civil service, and its close cooperation with state management. In addition to all these state management control has become stronger. The Mötv. — as opposed to the former law — does not include an itemised list of duties to be accomplished compulsorily by every local government, it only gives a task "menu" and its frame is filled with content by the sectorial laws. According to the new regulation the compulsory tasks of the municipal governments have tightened significantly. [2]

The law enumerates water management and water damage defence among local public affairs and local governance tasks accomplished among the locally assured public duties. [9: para. 13 (1) 11.] The local governmental law and the law of water management also define the water damage defence, and flood and inland water drainage as a local governance duty. [3: para. 4 (1) f)]

According to the law of water management it is the duty of the local governments to establish defences on behalf of at most two settlements, to maintain and improve them and to accomplish their protection. Their further duties are building and maintaining defences in periphery and inner-city areas and to implement defence on them to prevent damage caused by floods of brooks and channels, in addition to rainfall and other water. [3]

\section{Local governance duties in connection with defence}

\section{Period of preparation}

The first and most important step of preparation for the duties of water damage defence, as defined by the regulations, is the completion of the necessary plans on behalf of prevention after the identification of the level and risk of endangerment. The water authorities provide the required data for the completion of the plans with appropriate professional content and they give the needed help for the assembly of the defensive supplies. [4: para. 9 (1-3)] The completed water damage defence drafts are approved by the water authority in its territory 
of professional guidance and a copy of it is given to the mayor's office and the water authority. [5]

On the basis of what was written previously, forming the required amount of defence supplies, as predefined in the settlement, is also the duty of the settlement itself. These con- tain those instruments and technical materials that might be necessary to combat the ensuing flood. Supplies that can be minimally expected: pumps, sandbags, shovels, planks, rubber- boots, raincoats.

The technical materials are not worth much if there is no operative staff delegated to them. In the settlements, after the classification into the disaster protection departments, the obligatory civil defence organizations are established according to the level of risk.

Technical damage liquidation subunits need to be established in every settlement and water damage defence is among their duties. The mayor should organize citizens into civil defence organizations with economizing orders. After their establishment, the organizations have to obtain basic and professional training on where they can acquire the necessary knowl- edge, on the basis of which they can accomplish their duties. In the settlements, training has to be organized periodically for the civil defence organizations where they can extend their previously acquired knowledge.

\section{Period of defence}

In the settlements, the state management tasks related to the flood and inland water defence are controlled by the mayor (lord mayor) and he participates in the execution of the tasks published in the resolutions issued by the defence committee of the county. The mayor's duty in the settlement is registering and providing the workforce — including the men posted in the civil defence organization and the public workers - materials, tools and equipment for defence, furthermore the general supply of those who participate in the defence - including the men posted in the civil defence organization and the public workers.

In case of evacuation it is the mayor's duty to organise the execution of evacuation, rescue and return. He has to arrange proper measures in connection with life and property insurance and take other steps necessary for the rescue. Moreover he is responsible for the participants' health provisions, the measures for the prevention of epidemics during the procedures of evacuation, rescue and return and for the cooperation of the health administrative body. He is responsible for the arrangements taken in connection with the damage which occurred during the flood, inland water or defence, and alos the collection of the required bills and execution of the confirmations. [6]

\section{Period of reconstruction}

After finishing (or during) the defence, it is the settlements' duty to put in a claim on the basis of the relevant laws. The defence and reconstruction costs are assured by the "act of God" clause. The reconstruction process after water damage starts with disinfection. In this case the release of the properties is accomplished by the inhabitants under the professional guidance of the general health administrative department of the government office with the cleaning accessories provided by the local government. For the disinfection of the public domain and roads high-performance cleaning machines are needed which are available at the food safe- 
ty and animal health board of the government. In such instances the disinfection tasks are coordinated by the county defence committee who involve the settlements in this progress.

If water related damage occurred in private real estate, buildings of the local government or roads it is necessary to estimate the damages beyond the 'act of God' clause declaration of loss. The group of experts for the assessment of damages are appointed by the chairman of the county defence committee who do the damage estimate after agreeing with the set- tlements. After the damage estimate and stating the form and extent of the mitigation of damages the mayor of the settlement makes a contract on how to relieve the damages of the injured parties. In this case the contracting is the duty of the settlements. The process of re- construction closes with the checking of the degree of the damage mitigation.

\section{The defensive operation of the settlements in Fejér County hit by the Danubian flood of 2013}

\section{Preparation for the flood defence}

Between May 30 and June 3 of 2013 there was a huge amount of rainfall, above the regional average, on the drainage area of the Danube and its effluents, in Bavarian and Austrian ter- ritories and consequently the Danube hit a new the highest water level (hereinafter: HWL). According to the forecasts they had to prepare for the highest flood protection of all time on the Hungarian parts of the Danube.

In consideration of the emerging serious situation a special meeting of the Defence Com- mittee of Fejér County (hereinafter: DCFC) was called by its chairman on 4 June. The com- mittee made decisions on starting the necessary tasks for the residents' protection. The local authorities issued the DCFC resolution to the flood-hit Dunaújváros and Martonvásár district Local Defence Committees (hereinafter: LDCs) who held their meetings as well. The mayors of the settlements hit by the flood and the representatives of the state management and local governing organizations participating in the defensive works were also invited to the meet- ings and they were given tasks by the LDC. These tasks were moving the permanent residents from the areas endangered by the flood, sectionalizing of the public utilities towards the pro- viders, orders for building temporary ramparts, ensuring protection of the empty properties and an increased degree of public safety.

According to the forecasts on the county's part of the Danube the water experts, the peo- ple participating in the defence and the affected local governments had to prepare for a cul- mination exceeding the HWL. The mayors of the settlements hit by the flood and the experts of the Central Transdanubian Water Directorate (hereinafter: CTWD) knew the area was to be exposed to the flood, and this was a great help in the preparation. Protection had to be ensured in Ercsi, Adony, Rácalmás, Kulcs, Baracs, Kisapostag and the city of Dunaújváros.

From two o'clock pm on 5 June the director of the Disaster Management Directorate of Fejér County (DMDFC) roused the Emergency Controlling Centre to action in continuous

24-hour shifts with the purpose of the coordination and control of the flood preparation tasks. Continuous duties were ordered for the guidance of the defensive tasks in the headquarters of the LDCs. 


\section{Accomplishment of the defensive duties}

The system of the defence direction made the regional and local decisions in time on the basis of which the defence of the settlements started and were in progress at the arrival of the flood. For the execution of the resolutions the mayors' positive attitude in the affected areas and the defence controllers appointed from the executives of the disaster protection directorate, who were appointed by the chairman of the DCFC based on the suggestion of the disaster protection director, were needed. [7: para. 13] CTWD provided experts for every settlement to support the technical tasks of the defence beside its duties accomplished in the state line of defence (in our county it is the part of the main road 6 between Ercsi and Kulcs). This largely improved the proficiency of the defence.

The local organization and system of defence direction were new for the mayors and the defence committees as well. [8: para. 27-28] In spite of this it worked properly and the orders set in the LDCs resolutions were accomplished entirely in the settlements. The employment of disaster protection officers appointed to disaster protection leadership increased the effi- ciency of the defence work in the settlements.

On site the disaster protection officers, the mayors and the water experts accomplished their duties at a high level of proficiency and consequently the evacuation of the inhabited land properties occurred in time and the building of the line of defence was accomplished trustworthily.

The organization of the work of the professional associations, volunteers and public workers defending the settlements, the distribution of the duties and their provision and ar- rangement required a high level of coordination and organization. The number of the work- force needed for the defence and the availability of materials and tools in appropriate quantity and quality were also essential. The task of the leaders of the settlements was very significant and indispensable in this duty system. This work could be accomplished in the most effective and successful way in this form of organization and control.

\section{Accomplishment of the defensive duties at the time of danger}

The flood exceeded the HWL in the county's section of the Danube at 10 o'clock on 10 June $(762 \mathrm{~cm}$ at the water-meter in Adony, the HWL was $739 \mathrm{~cm}$ till then). The Government in its order 191/2013 (VI.10.) proclaimed an emergency in Fejér county for the district of Marton- vásár and Dunaújváros from 12 o'clock on 10 June 2013.

After the proclamation of emergency the disaster protection officers took over the leader- ship of the defence [7: para. 46 (3)], the leaders of the settlements and the mayors helped and provided the necessary resources. Those settlements where the defence and reconstruction was effective were characterized by the cooperation of the disaster protection officers and the mayors of the settlements working properly and thus contributing to the efficiency.

\section{Summary}

In Hungary due to extreme weather and water movement there has been a struggle against the damage caused by floods for centuries. In the past decades defence has given continuous tasks to the water organizations, disaster protection, the local governments and the inhab- 
itants as well. The defencelessness against the damages could be decreased by collective effort. For this, it is necessary for the governing bodies and the individuals to take steps in their own territory. For the successful accomplishment of the defence duties the participants are required to work in a unified system. Necessary laws were passed in the fields of defence management, disaster protection, the local governments and the duties of water damage de- fence, the legal foundations are available for the unified accomplishment of the defence.

In the article I studied the defence work of the municipal governments in the altered legal environment in the period of preparation, defence and reconstruction. As a result of the legal environment's change a unified system was established in the field of organization and con- trol. In fact water damage defence is not an isolated activity but integrally connected to the local governments, the disaster protection tasks and the defence management system.

In a later part of the document I analysed the tasks achieved by the local governments in Fejér County during the Danubian flood of 2013. I established that the system of defence management has been altered on the basis of the laws which focused on a unified system. The opportunities of the defensive system have expanded with the increase of the defence scales and a broader society can be included in the duties. Every condition of defence was available in the period of the particular law and order in the framework of the legal possibilities. Due to the forecasts that the weather is becoming more extreme in the ensuing years we can expect smaller or bigger floods. Flood protection can be successfully accomplished according to the valid laws.

\section{References}

[1] BÁRDOS Z.: A területi rendeltetésű árvízvédelmi komplex polgári védelmi szervezetek szakkiképzésének szerepe az önkormányzati ár- és belvíz elleni védekezésben. (The role of professional training for the territorial jurisdiction flood defence complex civil organizations in local governmental flood and inland water defence.) Hadmérnök, V 3 (2010), 264280. http://hadmernok.hu/2010_3_bardos.pdf (downloaded: 2805 2014)

[2] FORGÁCS N.: Az új önkormányzati törvény - interjú a szerkesztőkkel Nagy Mariannával és Hoffman Istvánnal. (The explanation of the new municipal governmental act — interviews with editors: Nagy Marianna and Hoffman István.) HVGORAC Lap- és Könyvkiadó Kft. /www.hvgorac.hu/sites/portal/Default.aspx?page=journal\&article=interju_ hoffman_istvan.htm (download: 2107 2014)

[3] 1995. évi LVII. törvény a vízgazdálkodásról. (Act LVII of 1995 on water management.) http://net.jogtar.hu/jr/gen/hjegy_doc.cgi?docid=99500057.TV\&celpara=\#xcelparam (download: 1106 2014)

[4] 232/1996. (XII. 26.) Korm. rendelet a vizek kártételei elleni védekezés szabályairól. (Govermnent decree 232/1996. (26. XII.) on the defence rules against water damage.) http:// net.jogtar.hu/jr/gen/hjegy_doc.cgi?docid=99600232.KOR\&celpara=\#xcelparam (download: 1906 2014)

[5] 10/1997. (VII. 17.) KHVM rendelet az árvíz-és belvízvédekezésröl. (Government decree 10/1997. (17. VII.) KHVM on flood and inland water defence.) http://net.jogtar.hu/jr/gen/ hjegy_doc.cgi?docid=99700010.KHV\&celpara=\#xcelparam (download: 2506 2014) 
BÁRDOS Zoltán: Survey on the flood-prevention of municipal governments during the Danubian flood...

[6] 234/2011. (XI. 10.) Korm. rendelet a katasztrófavédelemröl és a hozzá kapcsolódó egyes törvények módositásáról szóló 2011. évi CXXVIII. törvény végrehajtásáról. (Government decree 234/2011. (10. XI.) on disaster protection and the accomplishment of the Act CXXVIII of 2011 on the amendment of the related acts.) http://net.jogtar.hu/jr/gen/hjegy_doc.cgi?docid=A1100234.KOR\&celpara=\#xcelparam (download: 08 07 2014)

[7] 2011. évi CXXVIII. törvény a katasztrófavédelemröl és a hozzá kapcsolódó egyes törvények módositásáról. (Act CXXVIII of 2011 on disaster protection and the amendment of the related acts.) http://net.jogtar.hu/jr/gen/hjegy_doc.cgi?docid=A1100128.

TV\&celpara=\#xcelparam (download: 0907 2014)

[8] 2011. évi CXIII. törvény a honvédelemröl és a Magyar Honvédségröl, valamint a különleges jogrendben bevezethetö intézkedésekröl. (Act CXIII of 2011 on national defence and the Hungarian Army as well as the acts initiated in special law and order.) http://net.jogtar.hu/jr/ gen/hjegy_doc.cgi?docid=A1100113.TV\&celpara=\#xcelparam (download: 1207 2014)

[9] 2011. évi CLXXXIX. törvény Magyarország helyi önkormányzatairól. (Act CLXXXIX of 2011 on the local governments of Hungary.) http://net.jogtar.hu/jr/gen/hjegy_doc.

cgi?docid=A1100189.TV\&celpara=\#xcelparam (download: 1406 2014) 